\title{
South Africa, International Law and 'Decolonisation'
}

\section{Christopher Gevers \\ ORCID iD: https://orcid.org/0000-0002-4975-4335}

\begin{abstract}
Despite the ongoing calls to 'decolonise' the University and its curricula, including those of its Law Schools, international law continues to be taught in South Africa with little or no reference to African international legal scholarship, or 'Third World Approaches to International Law' more generally. That these were absent from law school curriculums during apartheid is hardly surprising, but their continued omission since 1994 demands an explanation, and calls for introspection on the part of South Africa's international legal academy. This article will argue that, rather than being a simple omission, this silence is 'co-produced' by the myth actively propagated by South African international lawyers since 1994 that 'from 1948 to 1990, South Africa was in conflict with both the international community and international law' (Dugard 1997: 77). As the first part of the article will demonstrate, the opposition of the so-called 'international community' (generally figured to represent 'the West') to apartheid was late, partial and contingent (if not reactionary). More importantly, the claim that international law as a whole was opposed to apartheid is simply wrong. At best, the latter relies on the conflation of 'international law' with 'international human rights law', and even then it requires significant qualification and differentiation. After deconstructing this 'international law myth', the second part of the article will sketch out the 'contributionist' and 'critical' streams of African international legal scholarship that have emerged since the 1960s - focusing on the work of TO Elias and U. Oji Umozurike as archetypes thereof. In doing so, it will read the work of Elias and Umozurike through their literary counterparts - specifically Chinua Achebe and Ngugi wa Thiong'o - in order to highlight the importance of bringing context (political and intellectual) to the reading of this scholarship, while acknowledging the role (and limitations) of international law as a discipline and as a vocabulary of emancipation.
\end{abstract}


Keywords: Third World Approaches to International Law, South Africa, Decolonisation, African History, African Literature.

\section{Introduction}

In January 1962 Kwame Nkrumah, in a speech at the opening of Ghana's first Law School, set out the types of lawyers that the institution (and those in other 'developing states') should produce, noting: 'The lawyers needed in a developing state are, in the first place, those trained to assist the ordinary man and woman in his everyday legal problems'; able to offer 'inexpensive but good advice [to] the ordinary man and woman so that they are not put at a disadvantage in dealing with a wealthy trading or commercial firm' (Nkrumah 1962: 107). This was necessary - Nkrumah continued - as 'the lawyer of colonial days who lived in the big towns ... spent most of his time in court or chambers dealing with a very restricted class of client', and therefore 'was very liable to become an exponent of the views of the colonial economic interests' (ibid). We might say that, in 1962, Nkrumah was calling for the Law School to produce lawyers that were 'decolonised' in the contemporary, colloquial use of the term. This much is hardly surprising, although it is worth noting that Nkrumah's vision of an ideal, decolonised lawyer is a far cry from that envisioned by the current South African LLB curriculum, which continues to prioritise 'the mass production of efficient and effective participants in the market' (Modiri 2014: 18).

What is surprising, is Nkrumah's next demand of 'decolonised' law schools, which he said was 'perhaps most important of all', namely: to produce lawyers 'to deal with treaties and commercial agreements and with questions of private and public international law' (Nkrumah 1962: 107). That Nkrumah was concerned about matters 'international' in itself is not remarkable. Ghana's first Prime Minister was an 'internationalist', who embraced 'a more globalised politics that emphasised supranational goals over national interest' (White 2003: 99), and at the time was working towards the establishment of a continent-wide political union (a 'United States of Africa'). Rather, it is Nkrumah's reference to international law that is intriguing, given the role that the discipline had played in colonialism (see generally Grovogui 1996; Anghie 2005; Pahuja 2011). One is left wondering what role Nkrumah envisaged for international lawyers in the continent's future, and indeed what type of 'international law' he had in mind. Unfortunately, unlike in the case 


\section{Christopher Gevers}

of their domestic counterparts, Nkrumah did not take up the opportunity to spell out precisely how international lawyers might be 'decolonised' (so that, unlike the 'lawyer[s] of colonial days', they did not become 'exponent[s] of the views of the colonial economic [and other] interests').

One explanation for Nkrumah's failure to do so is that he was simply unconcerned about the long shadow cast by colonialism over international law and believed that with the formal 'de-colonisation' of Africa, international law had become truly universal and, as such, there was nothing (or very little) that needed to be changed. At the time there were international legal scholars on the continent who held this benevolent view of international law as having been 'decolonised' by the formal demise of colonies, and who understood 'decolonisation' as 'fundamentally a matter of politics (in the most conventional sense), state sovereignty, and the transformation of colonies into independent nation-states' (Wenzel 2017: 450). On this basis. these scholars who would later become known as the 'contributionist' stream of African international lawyers (see Gathii 1998; 2012), embraced the United Nations (UN) and the post-1945 international institutional order, and proceeded to go to considerable lengths to shore up the 'universality' of international law historically by revealing its pre-colonial origins (see especially Elias 1972).

However, there is much to suggest that Nkrumah was unlikely to share a benign view of international law in 1962 (or, if he did, it did not last long). In 1960, Nkrumah had already warned the UN General Assembly that, in the ongoing crisis in the Congo, he saw the emergence of 'neo-colonialism, the process of handing independence over to the African people with one hand only to take it away with the other hand' (Nkrumah 1960: 5). On this version, so-called 'decolonisation' only granted African states 'clientele-sovereignty, or fake independence, ... a sort of independence [granted] by the metropolitan power, with the concealed intention of making the liberated country a clientstate and controlling it effectively by means other than political ones' (Nkrumah 1960: 5). As such, Nkrumah had called on the UN to 'face up to its responsibilities' to reign in those 'who would bury their heads like the proverbial ostrich in their imperialist sands' amidst continuing 'colonialism and imperialism, exploitation and degradation', warning that, '[t]he UN will be judged by the success or failure of its handling of [the] Congo situation'.

\footnotetext{
${ }^{1}$ United Nations General Assembly, Fifteenth Session, Official Records, $869^{\text {th }}$ Plenary Meeting (23 September 1960).
} 
By 1962 it was clear that the UN had failed that test, as under its watch Nkrumah's protégé, Patrice Lumumba was over-thrown and then assassinated in 1961, which was followed by Belgian and American military intervention in the Congo. This episode gave newly independent African states 'their first and altogether disagreeable taste of foreign intervention and of the cold war', according to Mohan, and also helped Nkrumah to expound the 'manoeuvres and machinations' of neo-colonialism 'before Africa and the world at large' (Mohan 1969: 369-370). Given the considerable (and unwarranted) ${ }^{2}$ faith and resources ${ }^{3}$ Nkrumah had already placed in the UN's mission in the Congo, it is likely to have also dampened any optimism he harboured for the institution or international law more generally. Nkrumah's ideal 'decolonised' international lawyer, then, is more likely to have embraced a critical disposition towards the discipline such as those who have emerged from Africa and the 'Third World' since the 1960s, and have set out the longstanding and intimate relationship between international law and colonialism, and its implication in the present, often using Nkrumah's very notion of 'neo-colonialism' (see Umozurike 1979: 128; Anghie 2005: 118). These scholars - loosely grouped under the banner of 'Third World Approaches to International Law' or TWAIL - have insisted that, '[t]he construction and universalisation of international law were essential to the imperial expansion that subordinated non-European peoples and societies to European conquest and domination', and that international law today remains 'a predatory system that legitimises, reproduces and sustains the plunder and subordination of the Third World by the West' (Matua 2000: 31).

Remarkably, despite the calls to decolonise 'the University' and its curricula, including those of its Law Schools (see Dladla 2012; Modiri 2016a), international law continues to be taught in South Africa with little or no reference to either one of these 'streams' of African international legal scholarship (i.e. 'contributionist' and 'critical'), or 'Third World Approaches to International Law’ more generally (see Gevers 2015; Fagbayibo 2019). That

\footnotetext{
${ }^{2}$ Mohan describes Nkrumah's decision to, 'look upon the UN as an instrument or ally in the African anti-imperialist struggle' as a 'grievous misjudgement', noting that ' $[\mathrm{t}]$ here was little warrant indeed for this view, in the light both the history and of the structure and procedures of the UN'. (Mohan 1969: 403-4). ${ }^{3}$ Ghana contributed 8800 of the 19929 troops that made up the UN Mission in the Congo (Asante 2019: 9). See further (Mohan 1969: 375).
} 


\section{Christopher Gevers}

these were absent from law school curricula during apartheid is hardly surprising, but their continued omission since 1994 demands an explanation and calls for introspection on the part of South African's international lawyers. In fact, one might be surprised to learn that, while South Africa's first international law textbook (Booysen's 1980 Volkereg: 'n Inleiding, an account 'invariably' sympathetic to the apartheid government (Dugard 1983: 335)) included a section on 'The African state's view of international law' (Booysen 1980: 21), none of the international law textbooks published since 1994 do. Rather, post-1994 international law textbooks generally adopt a 'universal' (read Euro-centric) approach to their subject, both historically and theoretically (see Gevers 2015).

This article will argue that, rather than being a simple omission, this silence is 'co-produced' (in the sense that it is both the cause and effect of) by a myth actively propagated by most South African international lawyers since 1994: namely that 'from 1948 to 1990, South Africa was in conflict with both the international community and international law' (Dugard 1997: 77). As the first part of the article will demonstrate, the opposition of the so-called 'international community' (generally figured to represent 'the West') to apartheid was late, partial and contingent (if not reactionary); and, more importantly, the claim that international law as a whole was opposed to apartheid is simply wrong. At best, the latter claim relies on the conflation of 'international law' with 'international human rights law', and even then, it requires significant qualification and differentiation. After deconstructing this 'international law myth', the second part of the article will sketch out the 'contributionist' and 'critical' streams of African international legal scholarship that have emerged since the 1960s - focusing on the work of T.O. Elias and U. Oji Umozurike as archetypes thereof. In doing so, it will read the work of Elias and Umozurike through their literary counterparts - specifically Chinua Achebe and Ngugi wa Thiong'o - in order to highlight the importance of bringing context (political and intellectual) to the reading of this scholarship, while still recognising the particular nature (and limitations) of international law. It will end by situating international law within the context of the so-called 'decolonial' turn in the South African academy more broadly, and the emerging critiques thereof (see Ramose 2020: 271-307).

\section{Deconstructing the 'International Law Myth' in South Africa}

In 1997, John Dugard, South Africa's pre-eminent international lawyer, intro- 
duced the new South African Constitution to readers of the European Journal of International Law as follows:

For over forty years, from 1948 to 1990, South Africa was in conflict with both the international community and international law. Apartheid, premised on race discrimination and the denial of human rights, was contrary both to the law of the UN Charter and to the norms of human rights, non-discrimination and self-determination generated by the post-World War II order. Although South Africa's foreign policy during this period was highly legalistic, it was the old law of state sovereignty and absolute respect for domestic jurisdiction that guided and shaped it. So it was that South Africa became a pariah state within the international community; a delinquent state in the context of the 'new' international law of human rights (Dugard 1997: 77).

In doing so, Dugard set out what has become the central myth of international lawyers in post-1994 South Africa, neatly captured by the claim by another prominent South African scholar that '[i]nternational law was seen as the progressive 'other' of Apartheid: the adequate, civilised, and principled response to all the illegalities and indignities that resulted from systemic racial discrimination' (De Wet 2004: 1532; see further Dugard 1995: 241; Botha \& Olivier 2004: 29).

In the years following the adoption of the 'Final' Constitution in 1996, this myth was commonly employed by South African international lawyers and courts to justify the "special place" that international law enjoyed under the new Constitutional order; in more recent times it has been used to bemoan the latter's imminent collapse (see van der Vyver 2015: 578). The 'international law opposed apartheid' assertion performs a double erasure. First, by beginning in 1948, the myth occludes the longer relationship between apartheid and international law; namely the origins of apartheid in early 20th century policy of 'racial segregation' - 'the ideological and political framework out of which apartheid was constructed and refined' (Dubow 1989: 1) - which was enabled if not encouraged by the White supremacist international order, without which first settler colonialism, then minority rule,

\footnotetext{
${ }^{4}$ Glenister $v$ President of the Republic of South Africa and Others 2011 (3) SA 347 (CC), para. 97.
} 


\section{Christopher Gevers}

would not have been possible (see Mills 1997). The relationship was exemplified by the prominent role of Jan Smuts in the establishment of both apartheid and this international order (see Dubow 1989; Mazower 2009; Reynolds 2012); in fact, Smuts himself argued in 1929 that the 'new policy' of segregation that would later become apartheid was itself 'enshrined in the Covenant of the League of Nations' (Smuts 1930: 88). Notably, this understanding of apartheid as the continuation of colonialism was adopted by African states and international legal scholars alike, who understood the struggle against apartheid as 'related to, and animated by, the wider anticolonial struggle for self-determination' (Black 2009: 81, see further Klotz 1995: 46). As Reynolds notes (2012: 205), following the admission of Third World states, the UN General Assembly's resolutions 'began to employ the language of self-determination and emphasised apartheid as an inherent violation thereof, equating the rights of those subject to a regime of racial domination with those subject to colonialism and foreign occupation'.

By foreshortening the relationship between apartheid and international law, this myth also forecloses a more complex account of the relationship between colonialism and international law more generally, and the 'discourse on the other', 'premised on European cultural supremacy and a presumed racial superiority' (Grovogui 1996: 25; see further Anghie 2005, Gevers 2020, and generally Orford 2006) that animated all three (the very same discourse that de Wet employs unironically when she described international law as 'the progressive 'other' of Apartheid' (2004: 1532)). Notably, as TWAIL scholars have consistently pointed out, the production and management of 'others' by international law (as 'savages', 'barbarians', 'non-Europeans') did not end with formal decolonisation, but continues today in the guise of 'development' (see Pahuja 2011), combatting terrorism (see Anghie 2005), humanitarian intervention (Orford 2003) and so on. In its exclusive focus on apartheid post1948, the 'international law myth' draws on and reinforces another misconception that operates at the domestic level. As Ramose points out, the 'international' campaign against apartheid, especially in the West, had the 'infelicitous effect of misleading the gullible into the belief that apartheid in South Africa was the fundamental problem', and that once it was abolished 'all shall be fine' (Ramose 2007: 320). This, he argues, had the effect of reducing 'the question of freedom' in South Africa domestically 'to the problem of the constitutional recognition of the 'civil rights' of the conquered peoples of South Africa', through an 'an all-inclusive constitution' (Ramose 2007: 320). 
The result was a 'formal vacuous justice' that not only 'did not restore full, integral, and comprehensive and unencumbered sovereignty to the indigenous peoples conquered in the unjust wars of colonisation', but left intact the 'morality', and political legitimacy of the 'right of conquest' of the colonisers and their 'successors in title' (Ramose 2007: 319f).

The 'international law myth' not only draws on this 'spectacularisation' of apartheid (and concomitant erasure of colonialism) that Ramose identifies; as discussed below, it also further reinforces the ongoing reduction of the 'question of freedom' domestically by misrepresenting the broad-based and ideologically multifaceted international struggle against apartheid to one for 'civil and political rights' (and downplaying its more radical social and economic demands). All the while the intimate role of international law in the 'unjust wars of colonisation' falls further from view. The second erasure that this 'international law myth' performs is more complex, but equally significant: the claim that from 1948 onwards South Africa 'was in conflict with both the international community and international law' at best oversimplifies the opposition of the 'international community' to apartheid, and more importantly understates the continued role of international law and institutions in its maintenance. To the extent that the 'international community' is simply shorthand for 'the West' (as it often is) the claim requires considerable qualification to be plausible, as the West's opposition to apartheid was late, partial, and contingent (if not reactionary). As Black notes:

Leading Western governments were latter-day converts to the antiapartheid cause and were motivated as much by the desire to protect their economic and strategic interests as they were by a concern for the basic human rights of the South African majority. Moreover, their intervention, through sanctions, helped to structure a moderate, liberal transition which aided in securing civil and political rights for all South Africans, but effectively reduced the emphasis on addressing their social and economic rights through a more radical political and economic transformation (Black 2009: 106).

More importantly, the claim that international law as a law was opposed to apartheid is simply wrong. For one, what Dugard labelled the 'old law of state sovereignty' continued to be international law's central operating principle throughout, and even at its peak 'pariah status' South Africa enjoyed 


\section{Christopher Gevers}

its sovereignty in the fullest sense, in a way that formerly colonised states did not, and arguably still do not (as Anghie has shown, these states enjoy a distinctive 'Third World sovereignty ... manufactured by the colonial world to serve its own interests' (Anghie 2005: 215). Moreover, as of 1945 and for some time thereafter, apartheid was not 'contrary to the law of the UN Charter' (nor was colonialism for that matter (Reynolds 2012: 200)), and when it did become recognised as such, it was at the prompting of Third World states (see below). In fact, much of the efforts at the UN level against apartheid were undertaken, if anything, in spite of the provisions of the UN Charter, which preserved the anti-democratic political prerogatives of the Great Powers (and still do). As Klotz notes (1995: 53),

Third World pressure succeeded in organisational settings where majority voting prevailed [such as the General Assembly], but not in the Security Council, where Western permanent members vetoed comprehensive mandatory sanctions.

Even in the International Court of Justice, South Africa was able to avoid effective sanction despite the considerable efforts of African states, most controversially in the 1966 South West Africa case when the Court reversed its earlier decision and dismissed African states' claim on procedural grounds (a reversal which, we now know, was made possible by the extra-curial duplicity of the Australian Judge President Percy Spender (see Kattan 2015: 344). Finally, much of the success that was achieved by the UN's Special Committee on Apartheid involved the circumvention of the 'international legal order' by appealing directly to domestic civil society groups and constituencies in order to pressure their governments from below, as it were (see Stultz 1991: 13; Black 2009: 95; Klotz 1995: Chapter 6). All the while in the international economic sphere, whose governance Western powers had separated from the UN's political structure in 1945 and placed under the even less democratic 'Bretton Woods Institutions' (see Pahuja 2011: 18-22), South Africa's allies ensured its continued 'access to international loans through the World Bank and the International Monetary Fund', institutions which were both institutionally dominated by Western governments, and 'insisted on established financial standards of membership' which meant that 'countries could be excluded only if they had not fulfilled their financial obligations' (Klotz 1995: 49). In fact, in the 1970s, while the states and international 
lawyers of the Third World were trying (and failing) to restructure the global international economic order - in order to 're-fashion, or 'revolutionise', the [international] laws which lead to the reproduction of the relations of domination and exploitation' (Bedjaoui 1979: 255) - apartheid South Africa was enjoying its 'golden years', with the economy growing faster 'than almost any other capitalist country, [and] white living standards [going] ... through a veritable revolution' (O'Meara 1996: 116). This was in the context of continued 'capital infusions' from the West, in spite of the 'political upheaval in the 1960s and 1970s' (Klotz 1995: 8). The most generous reading of this 'international law myth' would be that it idealistically conflates 'international law' with 'international human rights law', crediting the former with the efforts of the latter, insofar as opposing apartheid is concerned. However, even this generous reading demands significant qualification and differentiation. For one, the opposition of international human rights law to apartheid did not begin in 1945, after all the references to human rights in the UN Charter's Preamble were at the hand of none other than Jan Smuts (Dubow 2008: 54 - 56).

While few histories of international human rights mention Smuts' role in introducing them into the UN Charter in 1945, just about all of them are likely to include Hersch Lauterpacht's An International Bill of the Rights of Man, published in the same year - the 'ambitious and revolutionary text' which served as the 'inspiration' for the 1948 Universal Declaration of Human Rights and a model for future human rights instruments (Sands 2013: vii). However, in 1945 (and subsequent editions) of the International Bill of Rights, Lauterpacht deliberately made the right to self-government subject to 'the law of the State' with the denial of this right to Black South Africans in mind, so as not to make their treatment 'a matter of direct and immediate international concern' (Lauterpacht (1945) 2013: 137-138). According to Lauterpacht, '[t]he position in South Africa [was] sui generis (unique), and it would be fatal to adapt fully the fundamental purpose of the Bill of Rights to exceptional situations of this nature' (ibid. 140). So, the opposition of international human rights law to apartheid does not begin in 1945, or 1948, but quite a bit later; in fact, it was only in 1971 that the International Court of Justice declared (in an Advisory Opinion in respect of South West Africa) that apartheid 'constitute[d] a denial of fundamental human rights' and was 'a flagrant violation of the purposes and principles of the Charter' (para. 131). Moreover, while much of the credit for the eventual 'development' of the prohibition of apartheid into an international human rights norm belongs to the global 'anti-apartheid 


\section{Christopher Gevers}

movement', this too requires further specification. Firstly, the opposition to apartheid was driven by Third World states and non-state actors (see Klotz 1995: 9; Stultz 1991: 5-7). From the moment of their admission into the UN, African states consistently opposed apartheid (see Table of 'Sanctions against South Africa, 1960-1989' in Klotz 1995: 5). Over time they were joined in their efforts by other states and non-state actors - including "traditional' human rights advocates based in the West' - to form the broad-based, transnational 'movement', but it remained largely spearheaded by 'Third World' states and non-state actors' (Black 2009: 80f). In fact, prior to the admission of African states to the UN in the 1960s, opposition to apartheid in the Western-dominated General Assembly was on the decline (Stultz 1991: 3f).

In 1958 South Africa, who had downgraded its presence in the General Assembly two years prior, 'restored its full participation in the UN due to a softening of the approach taken by the Assembly' (Reynolds 2012: 205). However, by 1964, when African states were trying to convince the International Court of Justice that there was 'significant evidence of the general acceptance of a legal norm of non-discrimination or separation on the basis of race [i.e. apartheid]', they could cite 33 General Assembly Resolutions in support thereof since 1945, over half of them had been passed since $1960^{5}$. Notably, African states opposed apartheid at considerable political, economic and human $\operatorname{cost}^{6}$, but their contribution is often side-lined in contemporary narratives (Klotz 1995: 10), including by proponents of the 'international law myth' who credit an undifferentiated 'anti-apartheid movement' (or the 'international community'). Secondly, and more importantly, while the opposition to apartheid (particularly in the General Assembly) was often expressed in the language of human rights, it cannot be reduced to that (on the tendency of the international human rights movement to side-line other 'emancipatory vocabularies', see Kennedy 2006: 133). According to Black (2009: 79),

${ }^{5}$ ICJ, South West Africa Cases (Ethiopia v South Africa/ Liberia v South Africa), 'Reply of the Government of Ethiopia and Liberia', (20 June 1964), pp. 502-503.

${ }^{6}$ According to Klotz (1995: 82f), 'SADCC's first comprehensive estimates of the damage from South African destabilization for the period 1980-1984 totalled $\$ 10$ billion, ... others estimated the annual price of destabilization at $\$ 4$ billion per year'. 
to understand the ultimate success of anti-apartheid mobilisation, one needs to understand its roots in the norms of anti-racism and anticolonial self-determination, as well as the support it derived from states and groups with more radical - indeed revolutionary - goals.

In fact, Black argues that 'most groups in the anti-apartheid movement had an expansive socioeconomic conception of the post-apartheid transformation' (Black 2009: 103), and were concerned 'less with human rights writ large than with the narrower principle of anti-racism or the ideological priority of socialism' (Black 2009: 106). However, at the time of the transition, 'motivated as much by the desire to protect their economic and strategic interests as they were by a concern for ... basic human rights', Western governments intervened to 'structure a moderate, liberal transition which aided in securing civil and political rights for all South Africans, but effectively reduced the emphasis on addressing their social and economic rights through a more radical political and economic transformation' (Black 2009: 106). By conflating the 'antiapartheid movement' with international human rights law, the 'international law myth' not only erases the movement's more radical elements, it glosses over how Western governments pushed a moderate, liberal (narrowly construed) 'human rights' agenda that came to structure the 'transformation' of South Africa. Ultimately, the reduction of 'the question of freedom' in South Africa's 'transitions' was as much a matter of design as it was 'infelicitous' (Ramose 2007: 320), and proponents of the 'international law myth' - gullible or otherwise - play an important role in its continuation. Much of this important detail is lost when 'the role of international law in the struggle for liberation in South Africa' is reduced to the post-1948 story of 'the international community, principally acting through the United Nations, to persuade or compel South Africa to abandon its racial policies' (Dugard 1991: 85 own emphasis). In the final analysis, the claim that international law opposed apartheid, or even that international human rights law opposed apartheid, obscures more than it reveals.

\section{African International Legal Scholarship: An Overview}

In the same year that Nkrumah opened Ghana's first Law School, the present and future African literati - including Chinua Achebe, Wole Soyinka, Es'kia Mphahlele and Ngugi wa Thiong'o - met at Makarere College in Kampala for 


\section{Christopher Gevers}

the 'first get-together of African authors writing in English anywhere in the world' ${ }^{7}$. Aside from its historic significance, the gathering would be remembered for the debate that emerged amongst participants regarding whether 'African literature' could and should be written in colonial languages, a debate that would be revisited time and again over the following decades.

The conclusion reached at Makarere, despite continued resistance from some, was that it was both possible and desirable to continue writing in English, albeit with irreverence (see Mphahlele 1962). The position was summed up in a 1964 essay by Chinua Achebe, the 'Father of African literature', in which he called on his fellow writers to accept the universal status of English brought about by colonialism (Achebe 1975). Six months prior, African international lawyers had assembled in Lagos for their own 'Makarere' meeting, of sorts - arranged by the American Bar Association as part of a global project on 'World Peace Through Law' - to 'consider ways in which lawyers could work together globally to strengthen international law and legal institutions' (Rhyne 1962: 1001). One prominent attendee was Taslim O. Elias - Africa's most successful international lawyer to date and the first President of the International Court of Justice from the continent - who gave a keynote speech in which 'support for the international rule of law was strongly advocated' (Reid \& Sams 1962: 650). In the end, the international lawyers at Lagos unanimously endorsed the universality of international law - as '[embodying] fundamental concepts of justice and morality common to civilised societies' - and committed themselves to 'working toward worldwide acceptance and application of the rule of law in all international relations' (Rhyne 1962: 1004f). This approach taken to international law in Lagos in 1962 has since come to be known as the 'contributionist' stream of African international legal scholarship (see generally Gathii 1998; 2012). According to Gathii (1998: 189), this scholarship 'is largely complimentary of the liberatory claims of principles such as self-determination as uncompromising tenets of world peace and indicators of the rejection of the colonial experience', and 'uncritically endorses the United Nations agenda in areas such as human rights and the right to development as having potential and being of continuing

\footnotetext{
7 The Conference was organised by the 'Mbari Writers' and Artists' Club of Ibadan', and was attended by 45 participants (writers, editors, literary critics and publishers). Conference of African Writers of English Expression, Makarere University College, 11-17 June 1962 (on file with author).
} 
benefit to the formerly colonised countries'. Central to this scholarship is a 'contributionist' historiography, which '[re-writes] international legal history to assail Eurocentricity and accommodate African participation', while backgrounding 'the imperial and mercantilist character of international law' (Gathii 2012: 412).

The writings of T.O. Elias - a considerable body of work spanning four decades - are emblematic of this stream of African international law scholarship: colonialism, apartheid and the Third World attempts to reform or revolutionise international law receive little attention, and when considered, are placed within a progress narrative of 'universal' international law generally, and the rise of the UN in particular (see, for example, Elias 1972: v). In his seminal Africa and the Development of International Law (1972), Elias declares the UN 'the best forum for the airing of grievances about decolonisation, apartheid, racial discrimination and colonialism'; then, having highlighted its founding principles and commitment to sovereign equality amongst states, says that 'there is little else that the new African states, jealous of their newly won independence, could wish or hope for' (Elias 1972: 24). Similarly, the South West Africa cases are discussed as part of the development of the International Court of Justice, and not the project of decolonisation (see Elias 1983: 350); while the project to create a New International Economic Order (NIEO) - the flagship project of Third World international lawyers during the 1970s - was notably absent from Elias' scholarship until the 1980s. These 'contributionist' international lawyers would most likely have been undeterred by Nkrumah's 'failure' in 1962 to explicitly call for the 'decolonisation' of international law or specify what that might entail (as he had done for the teaching of domestic law). For these international lawyers, 'decolonisation' was equated with formal 'independence and self-government' (Elias 1972: 32). Elias, for example, refers to 'the process of decolonisation [which] ... goes on apace until all [dependent and non-self-governing territories] become free and equal independent States' (Elias 1972: 47).

Contrary to how it is used today, for these international lawyers 'decolonisation' meant, quite literally, de-colonisation a 'stubborn etymological literalness' in which 'colonies are what get decolonised' and 'decolonisation is fundamentally a matter of politics (in the most conventional sense), state sovereignty, and the transformation of colonies into independent nation-states' (Wenzel 2017: 450). As such, Elias was not only apparently unconcerned by international law's role in the broader impacts of colonialism, 


\section{Christopher Gevers}

and its 'postcolonial' political, economic and cultural afterlives; he was even derisive of the then Organisation of African Unity's (OAU) attempts to combat economic 'neocolonialism' (Elias 1972: 128). In this 'thin' account of 'decolonisation', colonial forms - be they the novel written in English or international law - were neutral, if not natural; they were to be embraced, either pragmatically or even emphatically in order to be 'turned back' against the centre. It was this understanding of 'decolonisation' that underpinned the confidence with which both African writers and international lawyers embraced their respective colonial forms in the 1960s, confident that they could make the English language and international law 'their own' without residual colonial influences.

In a 1964 essay, Achebe set out his reasoning as to why African writers should accept the 'inevitability' of the use of English as a 'world language', albeit it one 'which history has forced down [Africa's] throat' (Achebe 1975: 59). His argument was largely pragmatic, noting (1975: 57f) that 'there is no other choice', given both 'the reality of present-day Africa' as a result of colonialism and 'the continent's size and diversity'. Notably, Achebe specifically dismissed the suggestion that as a form, literature written in English (or other colonial languages) might be inextricable from the project of colonialism, arguing that while 'it came as part of a package deal which included many other items of doubtful value and the positive atrocity of racial arrogance and prejudice which may yet set the world on fire', there was no need 'in rejecting the evil [to] throw out the good with it' (Achebe 1975: 58). On this basis, Achebe was confident about both African writers' ability to use English strategically, and English's capacity to be 'Africanised' to 'carry the weight of ... African experience' in the process (Achebe 1975: 59 - 62). African writers, he argued (1975: 61), should 'aim to use English which is at once universal and able to carry out [their] peculiar experience'.

Reading the scholarship of Elias through Achebe's 1964 essay reveals a number of similar assumptions regarding their respective colonial forms. First, like Achebe's communicative understanding of colonial languages, Elias' understanding of international law was pragmatic and instrumental; both argued that their 'inherited' colonial forms were potentially, if not already, universal. Second, and related to this, neither Achebe or Elias considered whether these colonial forms might contain structural biases that required 'decolonising' themselves, both were confident that these forms could be repurposed, and that their relationship to colonialism was in the past. 
The general agreeability amongst African writers at Makerere in 1962 would soon fade, and over the decades that followed they returned critically to the questions that animated their inaugural gathering. This shift amongst some African writers was dramatically illustrated by the 'about-turn' by Kenyan novelist and playwright Ngugi wa Thiong'o, the heir-apparent to Achebe. As part of the younger generation of writers present at Makarere in 1962, Ngugi was amongst those who accepted the necessity of writing in English (see Ngugi 1986: 20). However, in 1979, Ngugi gave a speech at the Kenya Press Club in which he called for the abandonment of colonial languages by African writers, labelling their continued use 'neocolonialism' (Ngugi 1981a: 65). In that same year, U. Oji Umozurike published International Law and Colonialism in Africa (1979), which became a seminal text of the 'critical' stream of African international legal scholarship; that focuses on the 'role of economic, political, social and cultural superiority/inferiority in the historical relationship of colonised and colonising countries in the past and present', and 'expresses [its] desire for self-determination and autonomy from all forms of external or neocolonial controls' (Gathii 1998: 187). Crucially, this stream of scholarship is underpinned by a critical historiography that focuses on 'the imperial and mercantilist character of international law' (Gathii 2012: 412), and 'examines Africa's subordination in its international relations as a legacy that is traceable to international law' (Gathii 2012: 407).

The scholarship of Umozurike during the 1970s is emblematic of this 'critical' stream. In 1970 he published an article on 'International Law and Colonialism in Africa: A Critique' that told a very different story of international law, past and present to that of Elias (see Umozurike 1970a). Umozurike was centrally concerned with the anti-colonial struggles of the time - including apartheid - adopting a critical disposition towards the present international order and arguing that colonialism, racism and political economy (or 'neo-colonialism') continued to shape its contours. In his 1972 book, SelfDetermination in International Law, he argued (contra Elias) that the South West Africa cases 'demonstrate the close relations between international law and international politics' and the 'crudity and inequality that still persists in aspects of the international relations of black and white states' (Umozurike 1972: 220). Moreover, he took an early interest in the (New International Economic Order) project, arguing (1970b: 90f) for the right of newly independent states to nationalise foreign owned property under the principle of economic self-determination (without compensation in certain circumstances), 


\section{Christopher Gevers}

and insisting that '[p]olitical self-determination is ... incomplete without economic self-determination' (Umozurike 1970b: 99). Later, in International and Colonialism in Africa he noted (1979: 128) that ' $[\mathrm{t}]$ he call for a New International Economic Order is directed towards negating neo-colonialism.'

This critical stream tells a markedly different story of the history of international law, that of the 'contributionists', one that focuses at length on its relationship to colonialism in particular. For example, Umozurike's extended history of the discipline - set out in detail in International Law and Colonialism in Africa (1979) - begins with the slave trade and colonialism as ' $\mathrm{t}$ ] wo of the foremost experiences Africans had from contact with the Europeans' (Umozurike 1979: 1), and proceeds to discuss international law's role in both. He locates international law's origins in 16th century Europe 'when the African slave trade was growing roots' (Umozurike 1979: 7), noting that international law not only facilitated it but encouraged it. He proceeds to demonstrate (1979: 22-24) how African sovereignty was ignored or denied during colonialism (through settlement, annexation, Treaties of Cession, and so on), arguing that, not only was international law a 'handy instrument in the hands of the colonialists' up until 1918 (Umozurike 1979: 34), but that colonialism was intensified and consolidated under the League of Nations through the Mandates system and the unchallenged annexation of Abyssinia by Italy (Umozurike 1979: 51).

Throughout the remainder of the text, Umozurike refers back to the role of international law in slavery and colonialism ${ }^{8}$, its underlying racism and imperialism, and its persistence in the present, including through apartheid. For example, in his opening discussion of 'International Law and the African Slave Trade', Umozurike notes succinctly:

${ }^{8}$ Umozurike's history also differs from Elias in that it includes efforts of and by Africans, and those of African descent as well, to resist colonialism. He discusses the early 20th century history, includes a section on 'Pan-Africanism and Colonialism', and at various points he refers to these efforts (such as W.E.B. Du Bois' efforts at Versailles and the 1945 Pan-African Congress in Manchester). While acknowledging that these efforts lay outside of international law, Umozurike nevertheless suggests that 'the resolutions of the unofficial conferences had some influence, however small' (Umozurike 1979: 56). 
Europe gained immensely from the trade in African slaves at the expense of Africa. The prosperity of Western Europe and [the] U.S.A is partly based on the capital accumulated from the slave trade. The business encouraged in the Western World a feeling of racial and cultural superiority over the blacks. The South African apartheid policy originates in the Dutch contempt for his African slave (Umozurike 1979: 4).

In its critical approach to international law as a colonial form, Umozurike's scholarship and that of the critical stream more generally resembles the struggle that Ngugi set out in his relationship to writing novels in English. Ngugi elaborated on this struggle in Decolonising the Mind (1986), where he 'returned' to Makarere to ask: 'What was the route from the Berlin of 1884 via the Makerere of 1962 to what is still the prevailing and dominant logic a hundred years later?' (Ngugi 1986: 9). The answer, for Ngugi, lay partly in language's 'dual character' - as 'both a means of communication and a carrier of culture' (Ngugi 1986: 13) - and the failure at Makarere to consider the ongoing effects of the imposition of colonial languages as a form of cultural imperialism, which had led to their acceptance of the 'fatalistic logic of the unassailable position of English in [African] literature'; a logic, he added, 'embodied deep in imperialism' (Ngugi 1986: 20). For these and other reasons, Ngugi argued, the continued use of colonial languages was simply neocolonialism: there was essentially no 'difference between a politician who says Africa cannot do without imperialism and the writer who says Africa cannot do without European languages' (Ngugi 1986: 26). The colonial form could not, as Achebe would have it, be redeemed through 'Africanisation', nor could its effects be downplayed on pragmatic grounds.

The title of Ngugi's Decolonising the Mind usefully records the shift from a 'literal' construction of decolonisation as an event, towards a thicker account in which there are 'objects that are to be decolonised' (Wenzel 2017: 458), or abandoned: including African literature and, perhaps, international law. This understanding of decolonisation as action (rather than event), something that gets done to colonial forms (colonial languages, statutes, curricula, and so on) is what prevails today. The beginnings of this shift can be seen in Umozurike's International Law and Colonialism in Africa. To start, Umozurike explicitly abandons Elias' 'literal' conception of de-colonisation, refusing to conflate decolonisation with formal independence (Umozurike 


\section{Christopher Gevers}

1979: 126). Umozurike's aim to 'show ... the proper role of the international community in decolonisation' (Umozurike 1979: x), proceeded from a capacious definition of colonialism (centred on economic, cultural and political exploitation), and the understanding that 'neo-colonialism' was ongoing (despite formal independence) and that full sovereignty was not yet 'a reality' for African states (Umozurike 1979: 126).

While Umozurike did not go as far as Ngugi in calling for abandoning international law as a colonial form altogether, as I have argued in detail elsewhere (Gevers 2019), Umozurike's struggle with the inevitable limitations of using 'techniques and a language borrowed from the occupier' (Fanon 1961: 159) plays out in the ambivalences, contradictions, unevenness and lapses in genre throughout International Law and Colonialism in Africa, which are symptomatic of Umozurike's battle with the form of international law itself. To employ Wenzel's characterisation of Fanon's The Wretched of the Earth, Umozurike's is a text where 'the poetry of utopian possibility ... jostles with the prose of postcolonial disillusion' (Wenzel 2017: 458). In this sense, the most appropriate analogous Ngugi text is his 1977 novel Petals of Blood - his final novel written in English - in which many critics suggested Ngugi's battle with his 'borrowed' colonial form and its limitations was similarly evident in the text itself. As such, Chileshe's characterisation of Petals of Blood as a text that betrays an author's 'struggle against imperialist hegemony ... waged from within imperialist hegemonic structures', where 'even the weapons used [are] largely inherited from the culture at which the struggle is directed' (Chileshe 1980: 134), might be applied to Umozurike's International Law and Colonialism in Africa. Notably, as Pahuja and Eslava point out, this ambivalent approach to international law - a 'duality of engagement with international law - of resistance and reform' - is itself characteristic of TWAIL approaches to international law more generally (Pahuja \& Eslava 2012: 199).

The engagement with both of these 'streams' of African international legal scholarship, long overdue, is central to any attempt to 'decolonise' the teaching (and practice) of international law in South Africa. As this article has tried to demonstrate, albeit in outline, reading this scholarship through and alongside African literature is one way to situate it within a broader understanding of African intellectual history. In particular, the analogy to literature (and its limitations) is productive in two respects. First, it reveals the importance of context - both political and intellectual. The political context of the early 1960s, when the conversations at Makarere and Lagos took place, 
was very different from that of a decade later: a time of 'Independence, opposition politics, coups d'état, military government, one-party government; acres of poverty sprinkled with a few castles of wealth' (Mphahlele 1972: 54). It was a change in political context that brought about not only a 'new mood in African Literature' (Mphahlele 1972: 54), but in African international legal scholarship as well, as the 'contributionist' scholarship of Elias (written predominantly in the 1960s) came under fire from the 'critical' scholarship of Umozurike in the 1970s.

Equally significant was the different intellectual contexts within which Elias and Umozurike wrote: the different 'epistemological conditions' that made their scholarship 'both thinkable and feasible' (Mudimbe 1988: 195). For example, Walter Rodney wrote How Europe Underdeveloped Africa while he and Umozurike were both at the University of Dar-es-Salaam (see Rodney 1982: vii), and Rodney's influence on Umozurike's scholarship is hard to miss (and is acknowledged in the Preface to International Law and Colonialism in Africa (Umozurike 1979: x) $)^{9}$. So too is Fanon's, to whom Umozurike was much more likely to have been exposed during his time in Dar-es-Salaam than in his native Nigeria, particularly at the Law School where Fanon's work was compulsory reading (see Mazrui 2017; Batchelor 2017).

Beyond individual texts, changes in the broader intellectual contexts between the 1960s and 1970s inflected the work of writers and international law as well, as evidenced by the role of 'history' in their work. Elias' 'contributionist' history was written during the 'first stage of decolonising African history', when African historians 'were mainly concerned to beat back the assertion that Africa had no history... [by pointing] to kingdoms and large empires that did indeed have a political history that read like early aspects of European history' (Curtin 1981: 64; see further Ogot 1978: 29-33). Similarly, for Achebe the task of the African novelist, as he understood it at the time, was to write 'enabling stories' that centred on the pre-colonial past, even if, as in Things Fall Apart, such 'gentle re-creations of the past' (Achebe 2012: 115) glossed over 'the darker, more violent, and tragic aspects of the African experience' (Ogot 1978: 30).

${ }^{9}$ Rodney's influence can also be seen in Umozurike's reading; Rodney's 'Brief Guides to Reading' in How Europe Underdeveloped Africa (1972) include the works of W.E.B. Du Bois, George Padmore, and Eric Williams, which feature prominently in Umozurike's International Law and Colonialism in Africa. 
By the time Umozurike wrote his extended, critical history of international law in the 1970s, African historiography had changed considerably. According to Ogot (1978: 30), the 'honeymoon period' that 'dwelt rather nostalgically upon what was appealing or virtuous in the African past' was over, and African historians turned towards Marxist-inspired 'economic history' in order to address 'the present economic and political malaise in Africa' (notably, Ogot cites Walter Rodney's work as emblematic of this turn). Similarly, African writers were called upon to turn their attention to the present, and the narration of 'usable histories' that confronted its problems.

In 1972 Ngugi, drawing on Fanon, warned his fellow writers against 'becoming too fascinated by the yesterday of his people and forgetting the present' (Ngugi 1972: 44), a critique echoed by his protagonist in Petals of Blood, who criticises his professors for taking him 'to pre-colonial times ... [to] wander purposelessly from Egypt, or Ethiopia, or Sudan' (Ngugi 1977: 199) and instead calls for the study of the past 'critically, without illusions, [to] see what lessons we can draw from it in today's battlefield of the future and the present' (Ngugi 1977: 323). Like Ngugi's Petals of Blood, Umozurike's history of international law is directed at the 'battlefield of the future and the present', with consistent parallels being drawn between the racial and imperial aspects of 'colonial international law' and apartheid and neo-colonialism.

Reading African international legal scholarship through literature, then, renders a more complete account thereof, and in the case of early 'contributionist' scholarship, a more sympathetic one in particular (see further Gevers 2019). As Fanon counsels:

[W]e must shed the habit of decrying the efforts of our forefathers or feigning incomprehension at their silence or passiveness. They fought as best they could with the weapons they possessed at the time, and if their struggle did not reverberate throughout the international arena, the reason should be attributed not so much to a lack of heroism but to a fundamentally different international situation (Fanon 1961: 145146).

The comparison with African literature cuts both ways, however, revealing marked and troubling differences between the overall trajectory of these African international lawyers and writers over time. When Achebe actually returned to Makerere in 1968 it was as an envoy for the 'Republic of 
Biafra' that was attempting to secede from Nigeria, and the continent's first large-scale 'postcolonial' conflict formed the substance of his address, titled 'The African Writer and the Biafran cause' (see Achebe 1975: 78 - 84). It began with a history of Africa that was quite different to the 'gentle re-creations of the past' that typified his earlier works ${ }^{10}$. Rather, like Umozurike's International Law and Colonialism in Africa, Achebe's history now centred on the slave trade and colonialism, to which he added a third: decolonisation. According to Achebe, the Biafran war had demonstrated that 'decolonisation' was a farce: 'independence ... was totally without content' and ' $[t]$ he old white master was still in charge' (Achebe 1975: 82). This echoed Fanon's demands that the 'colonised intellectuals' must 'take part in the action and commit himself body and soul to the national struggle' (Fanon 1961: 167). Achebe argued that the role of African writers was to be part of 'the revolutionary struggle of their people for justice and true independence' (Achebe 1975:84). The following year he invoked Fanon's critique explicitly, noting that 'while the African intellectual was busy displaying the past culture of Africa, the troubled peoples of Africa were already creating new revolutionary cultures which took into account their present conditions'; and, as a result, African writers had been 'left behind' (Lindfors 1972: 5). The new task of the African writer was therefore 'to hurry and catch up with [the people] - to borrow the beautiful expression of Fanon - in that zone of occult instability where the people dwell' (Lindfors 1972: 6).

By the 1970s both Achebe and Ngugi had taken up Fanon's challenge to the 'colonised writer', to varying degrees: Achebe took up the Biafran struggle for self-determination (see generally Achebe 2012), while Ngugi's 'combat literature' aimed at the 'post-colonial' Kenyan state resulted in his detention and exile (see Ngugi 1981b). In fact, despite their generational differences, Achebe and Ngugi ended up in similar places; Achebe came to question the literal understanding of 'decolonisation as independence' and, although he did not give up on the colonial form altogether, his experiences in Biafra shook his faith in it (while he had been writing prolifically before the war, after it he did not write another novel for almost two decades).

${ }^{10}$ After the success of Things Fall Apart (1958), No Longer at Ease (1960) and Arrow of God (1964), the postcolonial anxiety had already begun to set in for Achebe in A Man of the People (1966). 
The interests of international lawyers fared quite differently during the same period. For one, the Biafran War did not have a corresponding effect on Elias' scholarship. In March 1970 he delivered a speech to the 'Nigerian Society of International Law' where he exonerated Nigeria of all allegations of violating international law (unsurprisingly, given his position as Nigeria's Attorney-General during the war). However, it was the issues Elias chose to focus on that dramatically demonstrated the distance between him and the emerging postcolonial critiques of Achebe: such as the effect of the conflict on the proper payment of oil royalties and the legality of 'mineral and other' concessions made by the 'so-called Republic of Biafra' to foreign companies (Elias 1971: 16f).

Ultimately, and not incidentally, Biafra turned out to also be significant professionally for Elias: his path to becoming a judge of the International Court of Justice was cleared when his compatriot Louis Mbanefo - who had already sat as a judge on that court before the war - sided with the fledgling Biafran Republic, and against Nigeria. In fact, in a symbolic act worthy of the poetic order, at the end of the Biafran war, Mbanefo - Nigeria's first ICJ judge - was part of the delegation that surrendered to (amongst others) Elias, its most successful to date.

That Achebe's writings changed while Elias' scholarship did not, is perhaps not that surprising, particularly in light of Elias' professional trajectory and his consistently orthodox approach to international law more generally. What is more difficult to explain away is the conservative shift in Umozurike's scholarship from the 1980s onwards - such that it ended up being indistinguishable from Elias'. In his final book, Introduction to International Law (1993), Umozurike recanted his critical approach in International Law and Colonialism in Africa altogether (see Umozurike 1993: 7). In particular, the history of international law he told in 1993 made no mention of the slave trade and spent less than a paragraph on colonialism (the two pillars of his previous critical history of international law); rather it recapitulated Elias' 'contributionist' history of 20 years prior (Umozurike 1993: 7-8). In fact, the first text on Umozurike's 'Suggestions for Further Reading' list for his introductory text was Elias' Africa and the Development of International $L a w^{11}$.

11 It is followed by Elias' New Horizons in International Law (1980). Umozurike's own International Law and Colonialism in Africa is number 10 
Therefore, while the comparison between these African international legal scholars and their literary counterparts is productive insofar as particular texts are concerned (and the political and intellectual contexts of their production), the longer political and intellectual arc of the two appears to diverge dramatically. Somewhat oversimplified, the international lawyers bend towards moderation if not conservatism, while the writers tend towards critique if not radicalism. More specifically, both Achebe and Ngugi became or remained sceptical of their 'borrowed' colonial form and ultimately rejected the thin understanding of 'decolonisation' as formal, political independence. Whereas, both Elias and Umozurike came to accept (or at least advance) the orthodox, Eurocentric account of international law and its relationship to colonialism, and rejected a thicker account of 'decolonisation' where - formal political independence notwithstanding - the Third World remains politically, economically and culturally subordinated by the West, in part through international law.

This suggests that 'decolonising' critiques that were thinkable (or perhaps say-able) in the 1970s were less so by the early 1990s, for international lawyers but not for writers (who continued to do so at a considerable cost). More importantly for present purposes, these 'decolonising' critiques of international law that were teachable in the 1970s were less so by the 1990s (certainly if Umozurike was doing the teaching) and may be even less so today. This can in part be explained by a disciplinary trend towards conservatism in international law; as Kennedy notes (1999 - 2000: 460), 'frame breakers' are often 'interpolated back into the disciplinary vocabulary' of international law, while Golder has shown how even the most critical international lawyers (like Kennedy) are susceptible to a 'redemptive' tendency in their scholarship (Golder 2014: 77). However, if Fagbayibo is correct in his recent assessment that ' $[\mathrm{t}]$ he teaching of public international law in Africa remains unresponsive to the imperative of decolonisation', and the critical approaches such as TWAIL 'remain marginal or non-existent' in curricula across the continent (Fagbayibo 2019: 172), then perhaps international lawyers on the continent are particularly resistant to critical approaches to international law.

Fagbayibo offers four explanations why this might be the case:

on the list (of 17 titles). Needless to say, Rodney and Fanon do not make the list. 
(1) 'the colonial heritage of legal education in Africa';

(2) a theoretically 'conservative posture that considers law in isolation';

(3) the 'triumph of neo-liberalism' within universities around the world; and

(4) 'chronic underfunding for research ... in many African universities [which] has ensured that the priority of advancing robust and critical pedagogical approaches remain at the bottom of the priority list' (Fagbayibo 2019: 182f).

The bad news is that, while these go some way to explaining the overall conservatism of African international legal scholarship in comparison to that in the 'Global North', they are less able to explain the apparent discrepancy amongst South African international lawyers in relation to the approach to teaching international law in the rest of the 'Third World'. The good news is that, to the extent that the challenges are resource-related (such as 'chronic underfunding for research'), South African universities enjoy a comparative advantage over many in the rest of the continent. As such, efforts to 'decolonise' the international legal academy in South Africa stand to benefit the rest of the continent, potentially. However, as this article has demonstrated, we still have some way to go in this regard.

\section{Conclusion}

In 1962, Kwame Nkrumah began his address at the opening of Ghana's first Law School by noting:

[In] opening these buildings we are reviving part of our African culture and heritage interrupted by the colonial period, and we are not embarking on any new venture. Long before the foundations of the universities of the European continent, law schools developed on African soil (Nkrumah 1962: 103).

These African 'centres of university life and learning', Nkrumah added, 'taught a system of law more advanced at that time than that existing in feudal Europe', in the idea that law 'must serve all men equally' (Nkrumah 1962: 103). The task of the Law School, then, was 'the general reconstruction of African action 
and thought and help to remould the generally distorted African picture in all other fields of life' (Nkrumah 1962: 105).

Since 1962, considerable and at times competing efforts have been undertaken by scholars across the continent towards the 'general reconstruction of African action and thought' (Nkrumah 1962: 105) regarding the international (legal) order, past and present. However, to date, international lawyers in South Africa have made little effort to engage with this scholarship - neither the pre-colonial traditions that Nkrumah referred to as he opened his 1962 address, that 'contributionist' international legal scholars have spent considerable energy excavating; nor the abundance of 'critical' scholarship that has emerged since then, which have grappled with international law's 'colonial and postcolonial realities', to borrow Anghie's phrase (Anghie 2006: 739).

This silence structures the field of international law in South Africa today, as what passes for common sense amongst many scholars, practitioners and judges - namely that 'international law opposed apartheid' - does not hold up to even a superficial engagement with this scholarship, or that of TWAIL more generally. The story is, at the very least, a little more complicated than that. In the end, it is this silence that is most perplexing, more so than the hold of the 'international law myth' (which, like many myths forged in the 1990s is wearing thin). After all, one can see the appeal to South African international lawyers of a story of triumph and renewal, in which local 'human rights warriors' make common cause with the 'international community' to overcome an evil, '[un]civilised', 'Other' (De Wet 2004: 1532). It is a story as likely to appeal to the enthusiastic, if a little 'gullible', new entrants into the field post1994, encouraged by the 'special place' international law enjoys in an equally triumphant 'new' Constitution; as it is to appeal to the older generation of international lawyers who might nevertheless know or suspect that the story might conceal more than it reveals.

What is perplexing is that, in the age of 'decolonisation and Africanisation' (institutionally and financially incentivised of late), and calls to de-centre Europe, South African international lawyers cannot find their way to an established body of work helpfully called 'Third World Approaches to International Law', with a leading text equally helpfully titled Decolonising International Law (Pahuja 2011), let alone to the African international legal scholars past and present that continue to play prominent roles therein.

In point of fact: in 2006 the Editorial Board of the South African Year- 


\section{Christopher Gevers}

book of International Law decided that, "the time was ripe to reflect on the international law scholars who have emerged from the continent', and decided that henceforth '[e]ach edition of the Yearbook [would] ... feature an exceptional African international lawyer' (Botha 2006: 1).

The Yearbook duly profiled South Africa's John Dugard in 2006, another South African Navi Pillay six years later, then stopped. One wonders what might have happened had the Yearbook profiled a third South African, its founding Editor Hercules Booysen, and disclosed the role of White 'farmers, businessmen, professionals and ordinary people' from South West Africa (Booysen 2007: 129), domestic and international corporate interests, the legal profession's society and the apartheid government's propaganda machinery in the establishment of the Yearbook and the other South African international law journal: the Comparative and International Law Journal of South Africa (see Gevers forthcoming).

While the widespread acceptance of the 'international law myth' contributes significantly to this ongoing silence, there are other contributing factors as well. These include the prevailing Eurocentricism of South African international law textbooks, and their '(poor) engagement with theory' - in contrast to critical approaches which draw on Critical Legal Studies, poststructuralism, post-colonialism, Feminism and Critical Race Theory (Gevers 2015: 456;460f).

More generally, as Modiri points out (2014: 6;10), '[m]any law teachers in South Africa....approach their subjects as though colonialism and apartheid did not take place' and adopt 'some or other brand of legal positivism' (the very same 'highly legalistic' approach that Dugard associated with apartheid-era international law), which means international lawyers are less likely to stand out amongst their colleagues for this omission. A less forgiving, but equally important, explanation is that 'the majority of [South African] academics ... are simply not sufficiently trained or literate in nonEurocentric paradigms of thought emanating from the Global South' (Modiri 2016b).

So, while it is clear is that international law in South Africa stands ready to be 'decolonised', it is less clear whether we yet have the international lawyers to do this. Should they be forthcoming, efforts towards 'decolonisation' must begin with a comprehensive engagement with African international legal scholarship, but they cannot end there; as the second part of this article aimed to show, conditions past and present appear to work against 
a sustained critical engagement with international law on the continent. And while the critical scholarship that continues to emerge from the rest of the Third World is an important supplement, as Ramose points out in this issue it is important to place African intellectual contributions at the centre of any such project ('decolonial' or otherwise). This will require international legal scholars to move beyond the comfort of their discipline and engage with African thinkers from a diverse range of fields. As one such thinker noted almost a half-century ago, ' $[\mathrm{t}]$ he teaching of law is totally incomplete if it is not accompanied by a background of economic, social and political science, and even politics, science and technology' (Nkrumah 1962: 104). This article has tried to demonstrate how African literature might be one avenue for doing so, much work remains to be done.

\section{References}

Achebe, C. 1964. The African Writer and the English Language. Reprinted in Achebe, C. 1975. Morning Yet on Creation Day: Essays. London: Heinemann Educational Books.

Achebe, C. 2012. There was a Country: A Personal History of Biafra. New York: The Penguin Press.

Anghie, A. 2005. Imperialism, Sovereignty, and the Making of International

Law. Cambridge: Cambridge University Press.

https://doi.org/10.1017/CBO9780511614262

Anghie, A. 2006. The Evolution of International Law: Colonial and Postcolonial Realities. Third World Quarterly 27,5: 739 - 753.

https://doi.org/10.1080/01436590600780011

Asante, C. 2020. Ghana and the United Nations' 1960s Mission in the Congo: A Pan-African Explanation. Third World Quarterly 41,3: 470 - 486.

Batchelor, K. 2017. The Translation of Les Damnes de la terre into English: Exploring Irish Connections. In Batchelor, K. \& S-A. Harding (eds): Translating Frantz Fanon across Continents and Languages. New York: Routledge. https://doi.org/10.4324/9781315620626

Bedjaoui, M. 1979. Towards a New International Economic Order. New York: Holmes \& Meier.

Black, D. 2009. The Long and Winding Road: International Norms and Domestic Political Change in South Africa. In Risse, T., S. Ropp \& K. 
Sikkink (eds.): The Power of Human Rights: International Norms and Domestic Change. Cambridge: Cambridge University Press.

https://doi.org/10.1017/CBO9780511598777.004

Botha, N. 2006. African International Scholars and their Contribution to the

Development of International Law. South African Yearbook of

International Law 31: 1.

Booysen, H. 1980. Volkereg: 'n Inleiding. Cape Town: Juta \& Co.

Booysen, H. 1984. Comment: Ten Years with the Yearbook. South African

Yearbook of International Law 10: viii - xv.

Booysen, H. 2007. An Academic Life over Continents. Pretoria: Interlegal.

Botha, N. \& M. Olivier 2004. Ten Years of International Law in the South

African Courts: Reviewing the Past and Assessing the Future. South

African Yearbook of International Law 29: 42 - 77.

Curtin, P.D. 1981. Recent Trends in African Historiography and their

Contribution to History in General. In Ki-Zerbo, J. (ed.): General History

of Africa I: Methodology and African Prehistory. Paris: UNESCO.

Chileshe, J. 1980. Petals of Blood: Ideology and Imaginative Expression.

Journal of Commonwealth Literature 15,1: 133 - 137.

https://doi.org/10.1177/002198948001500113

de Wet, E. 2004. Reception of International Law in the Jurisprudence of the

South African Constitutional Court: Some Critical Remarks. Fordham

International Law Journal 28: 1529 - 1565.

Dladla, N. 2012. Decolonising the University in South Africa: A Precondition for Justice. In Africa Institute of South Africa (ed.): Peace and Security for African Development. Proceedings of the Sixth Annual AISA Young Graduates and Scholars (AYGS) Conference. Pretoria: Africa Institute of South Africa.

Dubow, S. 1989. Racial Segregation and the Origins of Apartheid in South Africa, 1919 - 1936. London: Palgrave Macmillan.

https://doi.org/10.1007/978-1-349-20041-2 PMCid:PMC401395

Dubow, S. 2008. Smuts, the United Nations and the Rhetoric of Race and

Rights. Journal of Contemporary History 43,1: 45 - 74.

https://doi.org/10.1177/0022009407084557

Dugard, J. 1983. Review: Volkereg: 'n Inleiding, by Hercules Booysen. South African Law Journal 100: 334 - 338.

Dugard, J. 1991. The Role of International Law in the Struggle for Liberation in South Africa. Social Justice 18,1: 83 - 94. 
Dugard, J. 1995. International Law and the 'Final' Constitution. South African Journal of Human Rights 11: 241 - 251.

https://doi.org/10.1080/02587203.1995.11827562

Dugard, J. 1997. International Law and the South African Constitution. European Journal of International Law 8: 77 - 92.

https://doi.org/10.1093/oxfordjournals.ejil.a015563

Elias, T.O. 1971. The Nigerian Crisis in International Law. Nigerian Law Journal 5: 1 - 18.

Elias, T.O. 1972. Africa and the Development of International Law. Leiden: A. W. Sijthoff.

Elias, T.O. 1979. New Horizons in International Law. Dordrecht: Martinus Nijhoff Publishers.

Elias, T.O. 1983. The International Court of Justice and Some Contemporary Problems. The Hague: Martinus Nijhoff Publishers.

https://doi.org/10.1007/978-94-017-4865-0

Fagbayibo, B. 2019. Some Thoughts on Centring Pan-African Epistemic in the Teaching of Public International Law in African Universities. International Community Law Review 21: 170 - 189.

https://doi.org/10.1163/18719732-12341397

Fanon, F. 1961. The Wretched of the Earth. New York: Grove Press.

Gathii, J.T. 1998. International Law and Eurocentricity. European Journal of International Law 9: 184 - 211.

https://doi.org/10.1093/ejil/9.1.184

Gathii, J.T. 2012. Africa. In Fassbender, B. \& A. Peters (eds.): The Oxford Handbook of the History of International Law. Oxford: Oxford University Press.

Gevers, C. 2015. Review: Introduction to International Law, by T.W. Bennet \& J. Strug. South African Law Journal 132: 450 - 462.

Gevers, C. 2019. Literal 'Decolonisation': Re-reading African International Legal Scholarship through the African Novel. In von Bernstorff, J. \& P. Dann (eds.): The Battle for International Law: South - North Perspectives on the Decolonization Era. Oxford: Oxford University Press.

https://doi.org/10.1093/oso/9780198849636.003.0018

Gevers, C. 2020. 'Unwhitening the World': Rethinking Race and International Law. UCLA Law Review 67,6.

Gevers, C. International Law's Extimate: Apartheid, Colonialism and International Law. (Forthcoming.) 
Golder, B. 2014. Beyond Redemption? Problematising the Critique of Human Rights in Contemporary International Legal Thought. London Review of International Law 2,1: 77 - 114. https://doi.org/10.1093/lril/lru001

Grovogui, S.N. 1996. Sovereigns, Quasi Sovereigns, and Africans: Race and Self-determination in International Law. Minneapolis: University of Minnesota Press.

Kattan, V. 2015. Decolonizing the International Court of Justice: The Experience of Judge Sir Muhammad Zafrulla Khan in the South West Africa Cases. Asian Journal of International Law 5: 310 - 355. https://doi.org/10.1017/S2044251314000125

Kennedy, D. 1999-2000. When Renewal Repeats: Thinking Against the Box. NYU Journal of International Law \& Politics 32: 335 - 500.

Kennedy, D. 2006. Reassessing International Humanitarianism: The Dark

Sides. In Orford, A. (ed.): International Law and its Others. Cambridge:

Cambridge University Press.

Klotz, A. 1995. Norms in International Relations: The Struggle against Apartheid. Ithaca: Cornell University Press.

Lauterpacht, H. 2013. An International Bill of Rights of Man, with an Introduction by Phillipe Sands. Oxford: Oxford University Press.

Lindfors, B. (ed.). 1972. Palaver: Interviews with Five African Writers in Texas. Austin: University of Texas.

Matua, M. 2000. What is TWAIL? American Society of International Law, Proceedings of the 94 ${ }^{\text {th }}$ Annual Meeting, 5-8 April 2000.

https://doi.org/10.1017/S0272503700054896

Mazower, M. 2009. No Enchanted Palace: The End of Empire and the Ideological Origins of the United Nations. Princeton: Princeton University Press. https://doi.org/10.1515/9781400831661

Mazrui, A. 2017. Fanon in the East African Experience: Between English and Swahili Translations. In Batchelor, K. \& S-A. Harding (eds.): Translating Frantz Fanon Across Continents and Languages. New York: Routledge. https://doi.org/10.4324/9781315620626-4

Mills, C.W. 1997. The Racial Contract. Ithaca: Cornell University Press.

Modiri, J. 2014. The Crises in Legal Education. Acta Academia 46,3: 1 - 24.

Modiri, J. 2016a. The Time and Space of Critical Legal Pedagogy. Stellenbosch Law Review 507.

Modiri, J. 2016b. In the Fall: Decolonisation and the Rejuvenation of the Academic Project in South Africa. Daily Maverick 16 October 2016. 
Available at: https://www.dailymaverick.co.za/opinionista/2016-10-16in-the-fall-decolonisation-and-the-rejuvenation-of-the-academic-projectin-south-africa/

(Accessed on 05 December 2020.)

Mohan, J. 1969. Ghana, the Congo, and the United Nations. Journal of Modern African Studies 7,3: 369 - 406.

Mphahlele, E. 1962. Press Report. Reprinted in Conference of African Writers of English Expression, Makarere College, Kampala, Uganda, 11 - 17 June 1962. (On file with author.)

Mphahlele, E. 1972. The New Mood in African Literature. Africa Today 19,4: $54-70$.

Mudimbe, V.Y. 1988. The Invention of Africa: Gnosis, Philosophy, and the Order of Knowledge. Bloomington: Indiana University Press.

Nkrumah, K. 1962. Law in Africa. Journal of African Law 6,2: 103 - 112.

Ogot, B.A. 1978. Three Decades of Historical Studies in East Africa, 1949 1977. Kenya Historical Review 6: 22 - 33.

O'Meara, D. 1996. Forty Lost Years: The Apartheid State and the Politics of the National Party 1948 - 1994. Johannesburg: Ravan Press.

https://doi.org/10.1177/089692059602200309

Orford, A. 2003. Reading Humanitarian Intervention: Human Rights and the Use of Force in International Law. Cambridge: Cambridge University Press. https://doi.org/10.1017/CBO9780511494277

Orford, A. (ed.). 2006. International Law and its Others. Cambridge: Cambridge University Press.

https://doi.org/10.1017/CBO9780511494284

PMCid:PMC6654698

Pahuja, S. 2011. Decolonising International Law: Development, Economic Growth and the Politics of Universality. Cambridge: Cambridge University Press.

https://doi.org/10.1017/CBO9781139048200

Pahuja, S. \& L. Eslava 2012. Beyond the (Post)Colonial: TWAIL and the Everyday Life of International Law. Journal of Law and Politics in Africa, Asia and Latin America 45,2: 195 - 221.

https://doi.org/10.5771/0506-7286-2012-2-195

Ramose, M.B. 2007. In Memoriam: Sovereignty and the 'New' South Africa. Griffith Law Review 16: 310 - 329.

https://doi.org/10.1080/10383441.2007.10854593 
Ramose, M.B. 2020. Critique of Ramon Grosfoguel's 'The Epistemic

Decolonial Turn'. Alternation 27,1: 271-307.

http://alternation.ukzn.ac.za/Files/articles/volume-27/14-Ramose-Fin.pdf Reynolds, J. 2012. Third World Approaches to International Law and the

Ghosts of Apartheid. In Keane, D. \& Y. McDermott (eds.): The Challenge of Human Rights: Past, Present and Future. Cheltenham: Edward Elgar Press.

Rodney, W. 1982. How Europe Underdeveloped Africa. Washington: Howard University Press.

Rhyne, C.S. 1962. World Peace through Law Conferences. American Journal of International Law 56: 1001 - 1026.

https://doi.org/10.1017/S0002930000200298

Reid, T. \& J.F. Sams 1962. Conference on World Peace through Law: Held at Tokyo, Japan and Lagos, Nigeria. American Bar Association Journal 48: 649.

Sands, P. 2013. Introduction. In Lauterpacht, H. (ed.): An International Bill of Rights of Man, with an Introduction by Phillipe Sands. Oxford: Oxford University Press.

Smuts, J. 1930. Africa and Some World Problems. Oxford: Oxford University Press.

Stultz, N.M. 1991. The Evolution of the United Nations Anti-Apartheid Regime. Human Rights Quarterly 13,1: 1 - 23.

https://doi.org/10.2307/762456

Umozurike, U.O. 1970a. International Law and Colonialism in Africa: A Critique. East African Law Review 3,1: 46 - 82.

Umozurike, U.O. 1970b. Nationalization of Foreign-owned Property and Economic Self-Determination. East African Law Journal 6: 79 - 99.

Umozurike, U.O. 1972. Self-Determination in International Law. Hamden: The Shoe String Press.

Umozurike, U.O. 1979. International Law and Colonialism in Africa. Enugu: Mwamife Publishers.

Umozurike, U.O. 1993. Introduction to International Law. Ibadan: Spectrum Law Publishing.

Van der Vyver, J. 2015. The Al Bashir Debacle. African Human Rights Law Journal 15: 559 - 579.

wa Thiong'o, N. 1972. Homecoming: Essays on African and Caribbean Literature, Culture and Politics. London: Heinemann Educational Books. 
wa Thiong'o, N. 1981a. Writers in Politics. Nairobi: East African Educational Publishers.

wa Thiong'o, N. 1981b. Detained: A Writer's Prison Diary. London: Heinemann Educational Books.

wa Thiong'o, N. 1986. Decolonising the Mind: The Politics of Language in African Literature. Harare: Zimbabwe Publishing House.

Wenzel, J. 2017. Decolonization. In Szeman, I., S. Blacker \& J. Sully (eds.): A Companion to Critical and Cultural Theory. Hoboken: John Wiley \& Sons.

White, E. 2003. Kwame Nkrumah: Cold War Modernity, Pan-African Ideology and the Geopolitics of Development. Geopolitics 8,2: 99 - 124. https://doi.org/10.1080/714001035

Christopher Gevers Lecturer School of Law University of KwaZulu-Natal gevers@ukzn.ac.za 